\title{
The Role of Digital Technology in Tourism Education: A Case Study of South African Secondary Schools
}

\begin{abstract}
This paper discusses how Information and Communication Technology (ICT) supports tourism teaching in South African secondary schools. The researchers conducted an in-depth case study with 24 participants. An analysis reveals that teachers recognise ICT as essential in exposing students to the tourism industry. This is especially the case in under-resourced schools, where learners do not have the financial means to participate in tourism activities. However, ICT is still limited in its integration as a pedagogical support tool. The major obstacles toward integration include: technology anxiety, lack of training, availability of resources, and learner resistance to use their personal mobile devices.
\end{abstract}

Keywords: Tourism Education, Secondary Schools, Information and Communication Technology, South Africa.

\section{Introduction}

Tourism is often introduced as a subject in formal education curricula because of the significant economic contribution of the tourism industry to the private and public sectors. This is especially the case in emerging economies in Asia and Africa (Hsu, 2015; Mayaka \& Akama, 2015; Cuffy et al., 2012). The setting for this study is South Africa, an emerging/developing country with a growing tourism industry. According to the World Travel and Tourism Council (2015), the total contribution of travel and tourism to South Africa's GDP in 2014 was 9.4\%; a figure estimated to increase to $10.4 \%$ by 2025 . Moreover, travel and tourism in the country now accounts for $9.9 \%$ of total employment (1,497,500 jobs) and is expected to increase to $11.5 \%$ by 2025 (WTTC, 2015). According to the South African Department of Tourism, the country welcomed a record number of foreign tourists in 2013 (10 million visitors): a 4.7\% increase compared to the previous year. South Africa reports a much higher tourist arrival growth (7.4\%) compared to the global average (4.5\%) for the period between 2011 and 2013 (South African Tourism, 2014).

Ultimately, tourism in South Africa is recognised as a key economic sector with potential for continuous growth. With its multi-sectoral supply chain, tourism is considered one of the most important sources of job creation in the country. Tourism growth in South Africa therefore demands a skilled and professional workforce. This implies that the local workforce should be aware of the nature and role of tourism, and should be able to evaluate its potential critically. Various strategies could be initiated to raise tourism awareness (Van Niekerk \& Saayman, 2013); one of them is the introduction of tourism as a school subject. At secondary level, tourism has been widely introduced at schools throughout South Africa since 2000.

Furthermore, coupled with the widespread impact of the South African tourism industry, information and communication technology (ICT) ${ }^{1}$ has rapidly penetrated the public sectors of the country. ICT affords novel opportunities for social and economic development, and this has especially been observed in the fields of both tourism and education (Anwar et al., 2014; Vandeyar, 2015). Yet, the many uses and implications of ICT for tourism education in South Africa are unclear and under-theorised as a research area (Adukaite, Van Zyl \& Cantoni, 2016; Adukaite \& Cantoni, 2016). Tourism education alone warrants sufficient research attention. For these reasons, the authors undertook a qualitative case study to determine the extent to which ICT supports tourism education in South African high schools. Additionally, the authors aimed to identify the barriers of ICT integration in tourism education. The study was designed as an exploratory analysis, based on 24 in-depth interviews with high school tourism teachers $(n=19)$, as well as tourism subject planners and advisors at the governmental level $(n=5)$.

\footnotetext{
${ }^{1}$ While there are some variations of the term, we use it interchangeably with digital technology, to refer to the array of electronic technologies that afford rapid information transfer and multimodal communication.
} 
The following sections present the research context, with specific focus on tourism education as well as ICT integration in the South African education system. The authors then present their theoretical framework and methodology, followed by a discussion of the most significant findings. Finally, conclusions are drawn, before stating some limitations, policy implications, and future research directions.

\section{Context}

\section{Tourism as a high school subject in South Africa}

With the advent of constitutional democracy in 1994, the South African government gradually introduced more practical and vocationally oriented subjects such as Tourism, Hospitality, Business Studies, Agriculture, Information Technology and related subjects for grades 10, 11 and 12. Postapartheid South Africa lacked skilled human resources and faced major unemployment; more vocationally oriented high school subjects were expected to help address such issues (Chili, 2013). Furthermore, tourism as a subject was expected to stimulate domestic as well as international tourism markets. This was because tourism awareness would be created among both students and their parents. Indeed, children can play an important role in the travel decision making process within a family (Van Niekerk \& Saayman, 2013). Pilot studies had been introduced in several schools as early as 1996, but gradual roll out at the national level happened from 2000 onwards (Umalusi, 2014).

Since 2000, tourism as a subject has seen significant growth in terms of the number of schools where it is taught, as well as the number of learners selecting it. The subject has grown from 120 schools and 2'968 learners in 2000 to 2'887 schools and 118'904 grade 12 learners in 2014 (Umalusi, 2014). To date, tourism is one of the most popular electives in high schools: up to $20 \%$ of all high school students select the subject (Allais, 2014). Furthermore, tourism is taught in all types of schools: from well-resourced private schools to under-resourced rural and township schools, even if it was expected that the subject would mainly benefit learners from (previously) disadvantaged communities (Shalem \& Allais, 2014).

Tourism is an elective subject and is taught through grades 10 to 12, for four hours per week. Ten main topics are covered in the three years: (1) Tourism Sectors, (2) Map Work and Tour Planning, (3) Tourism Attractions, (4) Culture and Heritage, (5) Green Tourism, (6) Foreign Exchange, (7) Tourism Trends, (8) Communication and Customer Care, (9) Regional and Domestic tourism, and (10) Marketing of Tourism Products. Moreover, the subject involves a practical project (Practical Assessment Task or PAT), which makes up $25 \%$ of the final certification mark. The National Department of Basic Education requires that the host school supplies the learners with necessary textbooks, maps, brochures and travel magazines in the classroom. Tourism teachers are requested to have access to internet resources in order to keep up with dynamic industry developments. The Department also recommends access to audio-visual resources and computers (Department of Basic Education, 2011). 


\section{Academic research on tourism education in South African high schools}

There is limited academic research on tourism education in South African high schools (Van Niekerk \& Saayman, 2013; Chili 2013, 2014; Pawson, 2002; Van Niekerk, 2004; Punt, 2010; Kuze, 2013). According to Chili (2013:34), there is a "total disquiet with a particular literature in South African tourism education in schools. [...] it's so scarce that it's an area for concern [...]"

Van Niekerk and Saayman (2013) conducted a controlled experiment with two high school student groups: the research group contained students and parents that had tourism as a subject, while in the control group, no students or parents had the subject. Results indicated that the travel patterns of families with children studying tourism were influenced; moreover, students who opted for the subject were likely to pursue a career in the travel and tourism sector. Chili $(2013,2014)$ conducted qualitative research with principals, teachers and learners from South African township schools. He observed a significant shortage of qualified tourism teachers, and claimed that "too few students coming out of the public school system view tourism as a viable career option" (Chili 2013:36). Chili raises serious concerns over the perceptions of tourism as a subject. He found that both learners and teachers perceived it as an "easy" subject. Some teachers also did not regard tourism as a discipline. Education scholars Shalem and Allais (2014) expressed their concern that a vocationally oriented curriculum of tourism is weak, and that it offers little to learners.

\section{ICT and education in South Africa}

Since the institution of democracy in 1994, the South African government has made important strides in both policy and practice to provide education for all. This has gradually been coupled with the use and adoption of digital technology at all levels of the education system. The implementation of technology has strongly permeated national discourses and approaches around learning and teaching. Stakeholders - managers, teachers, learners, and administrators - are widely encouraged to use and adopt information and communication technology to enhance educational practice and improve learning. These directives are strongly "embedded in the broader pragmatism of ICT for development (ICT4D), in which digital technologies support social and economic priorities" (Van Zyl, 2013:ii).

The notion of technology-enhanced education gained momentum in national policies such as the White Paper on e-Education (2004). Since then, a range of technology initiatives have been implemented at primary, secondary and tertiary level across the country. These have notably included the Khanya Project, initiated in the Western Cape Province in 2001, that aimed to install computer laboratories at all primary schools in the province within a decade. Today, there is a voluminous and growing body of research dedicated to the study of technology at all levels of education in South Africa. Cantrell and Visser (2011) offer a fairly recent discussion of the domestication of ICTs in provincial schools. They conclude that, despite its vast potential, the many purported benefits of ICTs have not been effectively realised.

The reasons for this are today well recognised, although, increase in complexity over time. Vandeyar $(2013,2015)$ describes some of the significant issues that continue to influence the integration of ICT into teaching and learning practice. Some of the critical issues are "systemic (access, policy guidelines, policy overload, systemic support, national curricula, teacher training) and others are meso-micro level issues such as school leadership, institutional culture, teacher competence, teacher professionalism and teacher pedagogy" (2013:249). While there is abundant research on these aspects in the African context (see Harris, 2015), there is little to no research on the use and impact of ICT to facilitate the learning and teaching of tourism, especially at secondary level. In this paper, we address this gap by conducting a qualitative study on the role of ICT in South African tourism education. 


\section{Conceptual-theoretical framework}

A great deal of energy and funds are dedicated to equipping South African schools with ICT, since it is recognised as a vital tool for educational development. Initially, digital technology was mainly used for administrative tasks (Chigona et al., 2010; Obijiofor, 2009). However, with the continuous penetration and advancement of technology, ICT usage is shifting toward interactive instructional platforms and tools. These facilitate more self-regulated learning and engagement (De Freitas et al., 2010). Modern technology has the potential to create authentic and innovative learning experiences for students. This, in turn, poses a challenge for educators. They are under constant pressure to learn new approaches and tools, and to become confident with their integration into educational practice. Sole physical access to technology is not sufficient to influence integration for teaching purposes or to increase student engagement (Weston \& Bain, 2010).

\section{Technology self-efficacy and anxiety}

Scholars have argued that the role of teachers is critical in adopting ICT (Sumak et al., 2011). The individual determinants of adoption can include attitudes, culture, skills (technical expertise), experience, as well as micro social interactions (Teo, 2011; Sumak et al., 2011; Van Zyl, 2013).

The construct of self-efficacy originates from Social Cognitive Theory (Bandura, 1977) and refers to a person's belief in their ability to perform a particular behaviour successfully. Bandura (1986) proposed the theory of human functioning, which regards the dynamic interplay of personal, behavioural and environmental impacts; it presents an agentic perspective, which means that humans can determine the course of their actions. Self-efficacy is argued as an important determinant of motivation, action and affect (Bandura, 1986). Moreover, it plays a major role in how challenges, goals and tasks are approached. Thus, people with high self-efficacy tend to believe that they can handle challenging issues and are able to recuperate faster from setbacks. Conversely, individuals with low self-efficacy do not believe that they can perform complex and challenging tasks well and are less confident in approaching these tasks (Bandura, 1986; Schunk \& Pajares, 2009). Because of its significance in predicting human behaviour, the construct of selfefficacy has been studied extensively in the education field (Klassen et al., 2011, Fanni et al., 2013). For example, concerning ICT, technology acceptance by teachers is influenced by teachers' computer self-efficacy (perceived ability to use computers, Teo, 2011) or their technology selfefficacy (perceived ability to use a specific technology, Holden \& Rada, 2011).

The fear of using computer related technologies (Leso \& Peck, 1992) defines the concept of computer anxiety: a common factor that inhibits ICT integration into the educational setting (Azarfam \& Jabbari, 2012). Scholars have found that technology experience and skills are inversely related to technology anxiety (Shah et al., 2012; Ekizoglu \& Ozcinar, 2010). However, some researchers argue that the increased use of ICT for teaching may inadvertently lead to an increase in technology anxiety (Cotten et al., 2011).

\section{Technology domestication and barriers to integration}

Further to the above, not all determinants that influence adoption exist at the teacher level. Indeed, the teacher is always embedded within a broader context; that is, in a specific school with specific organisational characteristics, as well as within a wider community with different socio-economic characteristics. Firstly, a lack of resources and infrastructure, such as electricity, internet access, and physical space, remain key challenges in disadvantaged South African schools (Cantrell \& Visser, 2011; Obijiofor, 2009). Secondly, factors such as supportive leadership as well as technological assistance are needed to encourage teachers to integrate ICT for pedagogical and administrative purposes (Cantrell \& Visser, 2011; Czerniewicz \& Brown, 2009). Thirdly, the socio-economic contexts of teachers and learners can influence ICT usage for teaching and learning. In more 
affluent settings for example, students and educators might have access to computers and the internet at home. This might increase their confidence to use technology in the school environment (Muller et al., 2007). Similarly, in disadvantaged areas, the resource limitations to integrating ICT are far greater (Bladergroen et al., 2012).

Theories of technology domestication describe how people adopt technology in everyday life, with a focus on the role and use of technology, individual experiences, social behaviour and the function of acceptance and rejection (Haddon, 2006). The three main phases of domestication include (Habib, 2005; Haddon, 2006; Chigona et al, 2010):

(i) Commodification: the process of technology acquisition, expression of its symbolic and functional values, and evaluation of how it can fulfil specific needs.

(ii) Appropriation: users change their environment to adapt accordingly; technology is actively used and is integrated into formal (e.g., timetables) and informal structures (e.g., routines and habits). However, at this stage, technology is not necessarily accepted; potential adopters can yet reject it.

(iii) Conversion: the user-person wholly adopts the technology and displays it to the outside world physically or symbolically.

The conceptual framework of this research departs from the constructs of technology self-efficacy and anxiety, which serve as a lens to assess teachers' individual characteristics in adopting ICT for tourism education. Moreover, technology domestication theory is a useful perspective to investigate the complex factors that affect ICT integration for tourism education in South African high schools.

\section{Design and methodology}

The research reported in this article is an exploratory comparative case study. Fieldwork was conducted between April and June 2015 with ten high schools in the Metro North District of the Western Cape, and six schools in Western District in the Eastern Cape of South Africa. These districts were selected because of the diversity of their schools, ranging from urban to township institutions. Rural schools were not included in the study due to accessibility constraints experienced by the field researcher.

The main criterion for selecting schools was that they offer tourism as a subject. The names of high schools offering tourism were obtained from the Department of Basic Education. A convenient, non-probability sample was selected to include different types of schools in respect of their socioeconomic characteristics. Tourism is taught in all types of schools - from well-resourced private to poorly-resourced public schools. Table 1 provides an outline of the sample. 


\begin{tabular}{|c|c|c|}
\hline \multicolumn{2}{|c|}{ INTERVIEWEES } & \multirow[b]{2}{*}{ TYPE OF INSTITUTION / ROLE } \\
\hline $\begin{array}{l}\text { WESTERN } \\
\text { CAPE }\end{array}$ & $\begin{array}{l}\text { EASTERN } \\
\text { CAPE }\end{array}$ & \\
\hline 6 (5 schools) & 5 (4 schools) & $\begin{array}{l}\text { Public schools (Township). Previously, before 1994, only } \\
\text { black or coloured schools, inadequately resourced. }\end{array}$ \\
\hline 4 (3 schools) & 2 (2 schools) & $\begin{array}{l}\text { Public schools (ex-model C). Previously, before 1994, only } \\
\text { white schools, well resourced, now integrated. }\end{array}$ \\
\hline 2 (2 schools) & - & Private schools. Independent, well resourced. \\
\hline 1 & - & Tourism curriculum coordinator \\
\hline 2 & 1 & Tourism subject advisor \\
\hline \multicolumn{2}{|l|}{1} & National tourism curriculum coordinator \\
\hline \multicolumn{2}{|c|}{$\begin{array}{l}19 \text { interviewed teachers } \\
\text { (from } 16 \text { schools) } \\
5 \text { other interviewees } \\
\text { (from other institutions) }\end{array}$} & Total: 24 interviewees \\
\hline
\end{tabular}

\section{Table1: Outline of the sample}

In this article, the authors report qualitative data that resulted from in-depth semi-structured interviews with tourism teachers $(n=19)$ at the 16 visited schools. In addition, 5 interviews were conducted with government officials involved in tourism subject planning and coordination. These persons included a national tourism curriculum coordinator, a Western Cape tourism curriculum coordinator, two tourism subject advisors in the Western Cape, and one tourism subject advisor in the Eastern Cape.

In total, 19 tourism teachers were interviewed (12 in the Western Cape and 7 in the Eastern Cape), of which 16 were female and 3 were male. On average, respondents reported 6 years and 4 months (M: 6, SD: 3.6) of tourism teaching experience, ranging from 15 years to only one year of experience. Only two teachers were fully dedicated to tourism subjects; all others taught additional subjects like geography, business studies, languages, consumer studies, and history. Only three respondents had formal education related to tourism.

\section{Instrument}

The researchers used a semi-structured questioning approach to ensure consistency among respondents, while allowing for flexibility. Interviews lasted from 30 to 75 minutes and were conducted in English. All interviews were audio recorded and later transcribed. Transcripts were analysed using inductive thematic coding (Corbin \& Strauss, 2008), assisted by analysis software NVivo 10. Using the same coding scheme, an intercoder reliability test was conducted on $30 \%$ of the data to assess the extent of agreement on analysis of the content (Cho, 2008). A second coder was trained on the coding scheme and annotated the randomly selected sample of interview transcripts. The coders reached $83 \%$ agreement, which proved to be sufficient for social science studies, where .80 or $80 \%$ pairwise agreement is considered appropriate (Joyce, 2013).

\section{Ethical considerations}

Firstly, research approval was obtained from the Western and Eastern Cape Education Departments. Secondly, principals of the visited schools were contacted to obtain their permission to interview the respective tourism teachers. Thirdly, all respondents gave their written consent to be interviewed. They were informed that their participation was voluntary, anonymous and confidential. The main researcher commenced with fieldwork after becoming familiar with the context and environment (Sherry, 2008). 


\section{Results}

\section{ICT access, ownership and management}

Even though all interviewed teachers had some kind of material access to technology, less than half of the respondents integrated technology for tourism teaching on a regular basis. The majority of schools where ICT was integrated within the teaching experience were either private or ex model C (previously advantaged schools). When discussing ICT for tourism teaching, interviewees primarily referred to hardware requirements and limitations, such as data projectors, computers, televisions, and interactive whiteboards. Furthermore, they described the most used software and media for tourism teaching purposes. Microsoft PowerPoint, YouTube, Google search engine, Google Maps and Google Earth were listed as the most used and perceived as the most valuable programs for tourism instruction. Additionally, teachers described software that they used for sharing among colleagues, including Dropbox, WhatsApp and Google Drive. Other than hardware and software, teachers perceived the availability of a stable internet connection as a necessity:

Other than just sitting in front of that computer, you need to be able to access internet, because all the technologies are based there (Teacher, EC township school).

Respondents in the Eastern Cape had very limited access to internet at schools. Conversely, teachers in the Western Cape reported much better access to the internet. However, they commented on its slow speed. Teachers in schools with computers but limited or no internet reported on using CDs and DVDs with presentations, as well as videos and images obtained from the Department of Education or from other teachers.

I don't bring kids to the computer lab because we don't have internet. We have two data projectors in the school that they travel around the school. Mostly we show DVDs (Teacher, EC township school).

Interesting insights emerged related to the ownership and management of ICT in the schools. Only six interviewed teachers reported consistent access to schools' computer labs and classroominstalled technology. Three schools employed a sharing model (e.g. two projectors and/or TV set for the entire school); two teachers reported on buying their own hardware (data projectors); three teachers occasionally brought their own laptops to the classroom; and four teachers were using their own internet devices and data.

At the beginning we didn't have projector and that made my life very difficult so I went and bought my own projector and life became easier. I've got a dongle and my laptop that I use in the classroom and I put it through the projector and it works well. [...] The nice thing about teaching tourism is if you are computer literate you can get a lot of information from internet (Teacher, WC township school).

All interviewed teachers reported that their schools have mobile phone policies that disallow their use in the classroom. However, some teachers made an exception for tourism classes and occasionally allowed students to use their phones, because this would be the only type of technology available to them. In three cases (all in the Eastern Cape), teachers reported that students are encouraged to use community libraries.

Most of the referral resources in the curriculum are to the websites and we cannot access them because we don't have internet. If they [students] need to do research for their projects they use community libraries, or their phones (Teacher, EC township school).

\section{The value of ICT for learning: access, engagement, and authenticity}

A common issue that emerged through the interviews, especially in disadvantaged schools, is the fact that many students have never had touristic experiences. It is often challenging for them to relate to the content delivered through the subject. The National Department of Education suggests overcoming this by introducing various teaching strategies, educational trips, practical projects and technology supported teaching. However, the resources to facilitate this are scarce, especially in township and rural schools. The majority of respondents agreed that ICT (especially multimedia 
content such as videos and pictures) play a major role in overcoming learners' (and teachers') lack of tourism exposure:

Technology is our only hope to give a child some kind of experience of a tourism industry [...] be it movies, or showing video clips, PowerPoints, that kind of thing. But it needs to be interactive like 3D hotel room. This exposure is much better than nothing at all (Teacher, EC township school).

Furthermore, ICT also facilitates more authentic learning experiences:

We did the Colosseum in Rome with Grade 12 and I showed them a portion of "Gladiator", because I wanted them to realise that it's not another boring building. What is the value of this building? Because if you think what actually happened there and how much that is of history [...] (Teacher, WC private school).

Tourism has a reputation of being an "easy" subject, which in some ways becomes a "dumping ground" for academically weak students or those who try to but eventually cannot cope with other subjects. According to interviewed teachers, students rarely choose the subject because they are interested in it. Interviewees revealed that ICT has the potential increase their interest in the tourism subject:

They love it a lot, these sessions in computer lab, even the atmosphere in these lessons would change, because they are so interested and they are so excited, and even if the bell rings they don't want to leave (Teacher, EC township school).

Several teachers reported that, due to the nature of the subject, they need to look for creative didactic methods. ICT assists them in this regard:

I could stand and talk about bullfights in Spain but if you show them a video and they can visually see it makes such a big difference [...] I log in on Google Earth and tell them where in the world do you want to go? It pops up on the screen and it's amazing how they enjoy something like that (Teacher, EC, ex model C school).

Besides facilitating better delivery of the tourism curriculum, ICT literacy is important for students' future career paths:

If they go out there and they haven't done anything on the computers they are behind the rest of the workforce (Teacher, WC township school).

The ability to know how to use computer and especially how to do research on the internet were acknowledged as the most important skills that students would need after leaving school:

We don't stop talking about how we have to find ways in which we can use more electronic equipment. You cannot run away from it, cave men didn't run away from a wheel, so we have to embrace the technology and use it, it will only make things easier for us and students (Teacher, WC, ex model C school).

\section{The value of ICT for teaching: knowledge and interaction}

While uptake of tourism as a subject is rising at South African high schools, teachers who were and are supposed to teach the subject have not been trained sufficiently in subject content or in subject delivery. Tourism teachers are mainly self-taught with the help of short courses offered by subject advisors from the Department of Education.

Different teachers applied different techniques in gaining knowledge about the tourism subject such as travelling themselves, going through travel magazines, and studying textbooks. Six teachers emphasised the importance of online search engines, mainly for information research, and YouTube videos, for gaining knowledge:

It's been nerve-racking at the beginning. I started with a textbook; fortunately it had a CD in the back. [...] Just reading and going, taking module by module and researching them on the internet. For example, when they talk about in-room technology, what do they mean? [...] the internet has been invaluable (Teacher, WC private school).

ICT seemed particularly important for teachers to connect with other colleagues and share materials and knowledge. The most frequently mentioned ICT for this purpose was WhatsApp, email (mailing lists), Dropbox and Facebook. WhatsApp was particularly popular among interviewees: 
I WhatsApp a lot with other tourism teachers in the area. We do exchange a lot, they know I am the strongest in the world icons and time zones. The other teacher is stronger on currencies so we exchange" (Teacher, EC township school).

An interesting initiative was introduced by a group of tourism teachers in an Eastern Cape township. The group created a Dropbox account and started storing additional materials related to the curriculum such as presentations, tests, and worksheets in order to empower their colleagues in similarly disadvantaged areas:

We introduced this concept of Dropbox. It's a very good way of spreading stuff [...] it took us hours and hours of research. It's not the best but for the learners in the rural areas who never had access to any kind of technology it is at least something. Every teacher even in a rural area has a cell phone, so if they put Dropbox on their cell phones they can access all the information (Teacher, EC township school).

At the time of the interview (June 2015), around 60 users were subscribed to this particular Dropbox account.

\section{Technology anxiety}

As mentioned, the majority of tourism teachers have no formal training in the subject or in appropriate instructional approaches. Moreover, none of the interviewed teachers had any ICT training. Technology anxiety emerged as a major impediment for ICT integration into tourism teaching. Respondents were uncomfortable and intimidated to use ICT because of a perceived lack of skills and experience. As noted by a national tourism subject coordinator:

One of the reasons why the teachers are not using the technologies is because they themselves feel uncomfortable.

This argument emerged during the interviews with teachers as well, regardless of the type of school. For instance, one teacher reported:

I teach in the traditional method and it proved to be quite difficult when somebody suggests you can do this $\mathrm{x}, \mathrm{y}$ and $z$ with technology and I said 'oops', I don't know how to use this kind of media and I am just going to be in my little comfort zone and just, you know, do my work (Teacher, WC private school).

Furthermore, the availability of different ICT tools and platforms overwhelms teachers:

I don't know if it's good or bad but technology moves so fast, if you don't stay with it you are gone and there are so many, for example, different platforms. Many teachers feel overwhelmed. Where do I start? Which one do I use? Which one is better, which one is worse? And until we get to that stage, that unfortunately lies in teacher development (National subject coordinator).

Thus, a lack of skills and training on the integration of ICT in tourism teaching was recognised as a main source of resistance. However, training also requires resources (time and funding), and even in cases where teachers have access to such resources, usage is still limited:

I don't have time also for ICT training; obviously I am not using smart board to its full potential. There were talks about smart board training, but my board is nearly outdated and it's not happening. We just learn ourselves (Teacher, WC Model C school).

\section{Lack of resources}

Besides technology anxiety, another important finding related to the lack of ICT resources, as well as to logistical challenges to use available resources due to big classes, especially in township schools.

We have computer lab but you have to have special arrangements to go there, I do it twice a year I would say. It's difficult logistically because of our class sizes. All three my classes are 50+ [students] (Teacher, WC township school).

Only a minority of interviewed teachers had access to in-classroom technology. The majority of teachers were required to use their schools' computer labs. However, computer labs are mainly booked for IT-related subjects. As a result, tourism teachers have to be creative and flexible:

If I have a tourism topic that I know that the kids must see it, I try to arrange with CAT [Computer Application Technology] teacher and take them to computer lab, but it's very difficult for me to do that because of 
overlapping schedules and very often during my tourism period the lab is occupied by CAT students. What I would do either early in the morning or late afternoon or on the weekend I would take my kids and teach them with computers (Teacher, EC township school).

Furthermore, teachers are also constrained with time. Most classes are only 50 minutes long. By the time a teacher has helped 50 odd students with logging on the computer, the class would nearly be over. This has also been reported as a challenge in primary school environments (Van Zyl, 2013).

\section{Policies on mobile technology}

All interviewed teachers report that their schools have policies that disallow the use of mobile technology in the classroom. However, because it is a highly pervasive technology - "All the kids have smart phones; even the child from a squatter camp has got a smart phone" (Teacher, WC township school) - many respondents acknowledged the potential of mobile learning, and even making exceptions for tourism classes.

It's part of the rules, that kids cannot have cell phones in the classroom, but in the direction we are moving I cannot see how you can say that the kids cannot use cell phones. For educational purposes I allow them, if we don't have computers in the classrooms, that's our next best thing. The other day I had to take out my phone, because we were doing Kalahari Desert, I was trying to demonstrate to them, it's easy as this, just Google "Kalahari". I told this to my principal, what other way I could do? In my class I totally allow it. I am for cell phones in the classroom (Teacher, WC township school).

Tourism subject planners and advisors also agreed that mobile phones could be used for teaching and learning purposes:

$[\ldots]$ the cell phones are usually banned in the schools although you could use them as a way of teaching. I attended some of these training sessions where the teacher has a computer in the classroom and then she links to everyone's cell phone that is Wi-Fi connected and then she sends them 3 questions on their cell phones and then they have to answer those questions and they immediately can see what the responses are (WC subject advisor).

However, the use of mobile technology is further constrained because of students' and teachers' limited knowledge around its pedagogical applications.

We have free Wi-Fi at school and I would love to see mobile friendly programs for educational purposes, I would promote that to the kids. At the moment I use mainly Google to search information (Teacher, WC township school).

\section{Unfulfilled potential}

Several teachers raised concerns that students lack know-how in using their mobile phones for learning:

When it comes to our kids, they are coming from disadvantaged backgrounds, but many of them have smartphones, however, I still noticed even those who have smartphones would struggle using it for learning purposes. I ask them to open the internet and certain website; they don't know how to do it. When I say let's Google, they don't understand what I mean, even those with smart phones (Teacher, EC township school).

Students are hesitant to use their own internet data for learning mainly due to its cost. As stated by some respondents, students mainly prefer to use their cell phones for socialising, principally WhatsApp and Facebook, and for listening to music.

Two teachers reported that they made arrangements to allow students to work independently on their projects in the computer lab. However, they had to discontinue this practice:

I've asked IT lab but it didn't work because they end up playing games and using Facebook, so I've allowed them to bring in their own laptops and tablets, we set up our own IT lab over here (Teacher, WC private school).

Moreover, in disadvantaged schools, students' exposure to other technologies besides their mobile phones is limited. Therefore, according to one teacher: 
[...] if you bring technology into the rural school, the kids are not used to it, they get very distracted by it and for certain time you don't have their focus. They are not used to that kind of medium (Teacher, WC township school).

Lastly, one teacher explained that in certain instances, technology works against the teacher. This is counter-productive to the learning environment:

With technology it became very easy to copy and paste information [...] I asked to hand it [project] in handwritten not typed because when if it's typed they send to each other, change a couple of words and hand it in as theirs, therefore, I changed it to handwritten. In this case technology is working against the teacher (Teacher, WC township school).

\section{Addressing challenges}

Respondents also offered suggestions for overcoming technology anxiety and for harnessing the potential of ICT for tourism education. The principal reason for high technology anxiety seemed to be a lack of skills. Thus, the foremost suggestion was to receive increased training on subject content as well as teaching methods. Increased collaboration with more experienced tourism teachers and creation of opportunities for demonstrations and observations were acknowledged as potential strategies as well. This especially related to using digital technologies for content delivery, such as time zones or foreign currency exchange, which were identified as the most challenging for tourism students.

There are topics in curriculum such as time zones or forex [currency exchange] that learners struggle. I know teacher in East London who uses certain websites and videos to explain these topics and his students are very successful with exams. I network with him; I sometimes call him. [...] It would be useful to follow his lecture, listen how he teaches and see what technological sources he uses (Teacher, EC township school).

Furthermore, teachers wanted to take stronger advantage of mobile technology for educational purposes. Even though school policies strictly regulate the use of mobile phones in the classroom, several interviewees argued that mobile learning can complement and enrich formal learning in several ways: accessing educational resources, connecting with others, and sharing content. Finally, some teachers emphasised the potential of free digital tools available for content creation, sharing and networking, such as Dropbox and Google Drive.

\section{Discussion and conclusions}

The main goal of this explorative study was to investigate the role of ICT in secondary tourism education from the viewpoint of teachers. Departing from technology domestication as a conceptual framework, the study revealed that all interviewed tourism teachers had some kind of physical access to instructional technology. From a domestication theory perspective, 'technology commodification' was fairly achievable in the majority of these cases. Indeed, teachers expressed positive attitudes toward ICT-enhanced instructional tools: ICT has the capacity to widen access and provide more authentic learning experiences for students, as many of them have never been exposed to any touristic activity. Furthermore, ICT promotes student interest, engagement, and motivation. Teachers also believe that ICT is critical to students' future success, especially if they want to work in the tourism sector.

Notably, despite physical access and positive attitudes, some of the interviewed teachers did not use any form of ICT: their teaching was mainly textbook-based. Nearly half of the respondents ( 9 out of 19) could be positioned in the 'technology appropriation' phase of domestication. They quite actively use and integrate technology in their educational practice. This was either in the form of available in-room technology, taking learners to the computer lab, or bringing their personal ICT devices to work. Only four teachers could be located in a 'conversion' phase of domestication: they used technology regularly for curriculum delivery, for connecting with colleagues, and for sharing materials. These teachers also encouraged their students to use their mobile phones for learning. These findings are in accordance with previous studies on domestication of ICT in disadvantaged South African schools (e.g. Chigona et al., 2010; Bladergroen et al., 2012). In these studies, 
educators recognised and appreciated the benefits of ICT for instruction, but identified serious impediments to achieve technology conversion. These ranged from exogenous factors such as available infrastructure, to school culture, management approaches, and technology self-efficacy and anxiety.

Previous research (Bandura, 2002; Palak \& Walls, 2009; Agbatogun, 2010) suggest that there is a strong positive correlation between teachers' attitudes toward ICT and their self-efficacy. Despite positive attitudes exhibited toward ICT in this study, technology anxiety and the lack of confidence in using ICT were recognised as the foremost barriers preventing adoption.

The results of this study relate to Social Cognitive Theory (SCT) as various factors (personal, behavioural, and environmental) were identified contributing to teachers' confidence in using technology for instruction. On a personal level, many respondents highlighted that successful tourism teachers have to be self-starters and open to change in teaching methodologies. Regarding behavioural factors, it was acknowledged that those teachers who had more advanced skills and experiences with technology tended to integrate it more compared to those who lacked these skills and experiences. Technological know-how was due to some teachers' personal decision to learn how to adopt technology for teaching purposes in their free time. Considering environmental factors, interviewees identified various external barriers that hindered them from developing their skills with ICT and consequently integrating it in teaching practices. Such impediments included lack of time, daily work demands, lack of resources, and big classes (especially in township schools). The findings support the SCT construct of human agency, which operates in an interdependent, triadic, reciprocal and causal structure (Bandura, 1998, p.62). The causation involves various factors - personal, behavioural, and environmental - that influence each other and determine individual decisions.

Furthermore, Bandura (1977) identified four sources of efficacy: (i) Experience of mastery; (ii) Vicarious experience; (iii) Social persuasion; and (iv) Physiological arousal. Interviewees shared their suggestions, which would facilitate more confidence in using technology for instruction and some of these suggestions are aligned with Bandura's identified sources of self-efficacy. The main cause behind low levels of confidence in using ICT is a lack of skills and experience. This could be addressed through training and practicing with instructional technology and specific ICT tools and resources. In respect of vicarious experience, interviewees suggested the idea of intensifying collaboration with other teachers and observing how successful teachers employed technology in their tourism classes delivering certain topics. This can be beneficial in increasing technology selfefficacy as observing others performing intimidating practices without adverse consequences can generate confidence and belief in their abilities (Bandura, 1977). With regards to physiological arousal and in the situations where teachers fear that technology will break, it can be addressed with more training as well. According to Bandura (1977), stressful situations evoke emotional reactions that affect persons' beliefs about their competencies and abilities. Providing opportunities where teachers can learn and practice can decrease their fear towards instructional technology.

This study echoes similar challenges in tourism education reported in other developing or emerging countries, for example in Asia, as reported by Hsu (2015), who describes the main obstacles as limited educational resources, qualifications of faculty, and outdated educational materials. Similar results are reported by Harrison (2015) on tourism education in the South Pacific: he emphasised the lack of touristic exposure of learners, and the challenge of striking the right balance between vocational and academic aspects within tourism education. The findings of this research are also in accordance with those of Mayaka and Akama (2015) on tourism education in Kenya. The researchers concluded that the full significance of ICT in tourism curriculum content and design is still far from being apprehended. 


\section{Significance for theory and policy implications}

The findings of this study may be significant for broader theories and applications of technology adoption in education, especially in contexts beyond South Africa. As this research has shown, while digital technology is of significant utilitarian value for educators, it can have more emotive, symbolic and cognitive implications. Digital technology can facilitate the practical access to information and achievement of tasks, while broadening the cognitive horizons of learners by virtualising (or imagining) the tourism experience. Coupled with the use of mobile devices and digital services, tourism as a distant and improbable reality becomes a possible and lived experience. Research in the international context may look to this 'augmented' potential of technology in terms of tourism education.

Besides providing much needed research on the opportunities and challenges of ICT for tourism teaching in the concerned schools and regions, this article might also be of practical interest, both locally and internationally. Policies should consider the point of view of teachers, so to ensure higher levels of technology appropriation and conversion. In particular, (i) suitable technological infrastructure is needed, to serve not only the Computer Application Technology classes, but to also support other subjects, including tourism. (ii) The mere provision of ICT is not sufficient: specific training activities - both pre- and in-service - are needed in order to enable teachers to use them without anxiety. (iii) Such training should go beyond the technology itself, tackling the instructional design of the very subject of tourism, how ICT can support its teaching and learning, to provide more authentic and broader tourism experiences, as well as to further improve attention, interest and motivation. (iv) Teachers should become better able to use ICT also for their professional development and in order to exchange materials and share experiences with other colleagues. (v) Additionally, regulations about the usage of personal mobile phones by students might be revised to allow them to access specific, value-added activities. (vi) At a higher level, the selection itself of competent tourism teachers should be viewed as a critical factor of success, and (vii) ad-hoc communication activities might be advisable to improve the overall image of the subject.

\section{Limitations and future work}

This research has a methodological limitation connected to the selected schools' sample. There were no rural schools included in the sample due to accessibility constraints. Rural schools enrol a significant number of South African learners and face a series of challenges, which may be different compared to the reported schools in this article. Moreover, the country's linguistic complexity limited the researcher to include schools with English as the main language of instruction. Schools where Afrikaans and isiXhosa are the main language of instruction were excluded due to the field researcher's lack of knowledge of these languages.

Future work could specifically examine tourism curriculum content and attempt to understand the degree of localisation and the degree of ICT related usage.

\section{Acknowledgements}

The field research of this study was conducted under a Doc.Mobility fellowship (P1TIP1_155023) funded by the Swiss National Science Foundation (SNSF). 


\section{References}

Adukaite, A., Cantoni, L. (2016). Raising Awareness and Promoting Informal Learning on World Heritage in Southern Africa. The Case of WHACY, a Gamified ICT-enhanced Tool. International Journal of Education and Development using Information and Communication Technology (IJEDICT), 12(2).

Adukaite A., Van Zyl I., Cantoni L. (2016). The Role of ICT in Tourism Education: A Case Study of South African Secondary Schools. eReview of Tourism Research (eRTR). Special issue "ENTER2016" upcoming

Agbatogun, A. (2010). Self-concept, computer anxiety, gender and attitude towards interactive computer technologies: A predictive study among Nigerian teachers. International Journal of Education and Development using Information and Communications Technology, 6(2).

Allais, S. (2014). How Does Matric Measure the Health of our Education System? Public Positions at the University of the Witwatersrand, Centre for Researching Education and Labour School of Education. Retrieved from: http://bit.ly/1MzuctG

Anwar, M. A., Carmody, P., Surborg, B., \& Corcoran, A. (2014). The diffusion and impacts of information and communication technology on tourism in the Western Cape, South Africa. In Urban Forum (Vol. 25, No. 4, pp. 531-545). Springer Netherlands.

Azarfam A.Y., Jabbari Y. (2012). Dealing with teachers' technophobia in classroom, Advances in Asian Social Science, 2 (2) (2012), pp. 452-455.

Bandura, A. 1977. "Self-Efficacy: towards a unifying theory of behavioural change", Psychological Review, vol. 84, no. 2, pp. 191-215.

Bandura, A. 1986. "Social foundations of thought and action: a social cognitive theory", Englewood Cliffs, NJ: Prentice-Hall.

Bandura, A. (1998). Personal and collective efficacy in human adaptation and change. In J. G. Adair, D. Belanger, \& K. L. Deon (Eds). Advances in psychological science (pp. 52-71). Hove, UK: Psychology Press.

Bandura, A. (2002). Growing primacy of human agency in adaptation and change in the electronic era. European Psychologist, 7(1), 2-16. doi: 10.1027//1016-9040.7.1.2

Bladergroen, M., Bytheway, A., Chigona, W., Cox, S., Dumas, C., Van Zyl, I.J. (2012). Educator discourses on ICT in Education. International Journal of Education and Development using Information and Communication Technology (IJEDICT), 2012, Vol. 8, Issue 2, pp. 107-119.

Cantrell, S., \& Visser, L. (2011). Factors Influencing the Integration of Technology to Facilitate Transfer of Learning Processes in South African, Western Cape Province Schools. Quarterly Review of Distance Education, 12(4), pp. $275-285$.

Chigona, A., Chigona, W., Kayongo, P., \& Kausa, M. (2010). An empirical study on domestication of ICT in schools in disadvantaged communities in South Africa. International Journal of Education and Development using Information and Communication Technology, 6(2).

Chili, N. S. (2013). Tourism education: Factors affecting effective teaching and learning of tourism in township schools. Journal of Human Ecology, 41(1): 33-43.

Chili, N. S. (2014). The Ecology of Teaching: Efficiency, Efficacy and Effectiveness of Teaching and Learning of Tourism in Township High Schools. Journal of Human Ecology, 48(2): 299-312.

Cho, Y. (2008). Intercoder Reliability. In Paul J. Lavrakas (Ed.), Encyclopaedia of Survey Research Methods. (pp. $345-$ 346). Thousand Oaks, CA: Sage Publications, Inc.

Corbin, J., \& Strauss, A. (2008). Basics of qualitative research: Techniques and procedures for developing grounded theory. Thousand Oaks, CA: Sage

Cotten S.R., Hale T.M., Moroney M.H., O'Neal L., Borch C. (2011). Using affordable technology to decrease digital inequality, Information, Communication \& Society, 14 (4), pp. 424-444.

Cuffy, V., Tribe, J., \& Airey, D. (2012). Lifelong learning for tourism. Annals of Tourism Research, 39(3), $1402-1424$.

Czerniewicz, L., \& Brown, C. (2009). A study of the relationship between institutional policy, organizational culture and e-learning use in four South African universities. Computers and Education, 53(1), 121-131.

De Freitas, S., Rebolledo-Mendez, G., Liarokapis, F., Magoulas, G., \& Poulovassilis, A. (2010). Learning as immersive experiences: using the four dimensional framework for designing and evaluating immersive learning experiences in a virtual world. British Journal of Educational Technology, 41,69-85.

Department of Education, South African (DoE). (2004). White Paper on e-Education. Transforming Learning and Teaching through Information and Communication Technologies (ICTs). Notice 1922 of 2004. Government Gazette, No. 26726.

Ekizoglu N., Ozcinar Z. (2010) The relationship between the teacher candidates' computer and internet based anxiety and perceived self-efficacy. Procedia - Social and Behavioral Sciences, 2 (2) (2010), pp. 5881-5890.

Fanni, F., Rega, I., Cantoni, L. (2013). Using Self-Efficacy to measure primary school teachers' perception of ICT: results from two studies, International Journal of Education and Development using ICT, vol. 9, no. 1, 100111.

Habib, L. 2005. Domestication of learning environments in an institution of Higher Education, 33rd Congress of the Nordic Educational Research Association, A Nordic Dimension in Education and Research, Myth or Reality?, March 10-12, 2005, University of Oslo. 
Haddon, L. 2006. The Contribution of Domestication Research to In-Home Computing and Media Consumption. The Information Society 22 195-203.

Harris, J. U. (2015). The Promise, Prospects and Challenges of In-formation Communication Technology (ICT) Utilization in African Educational Systems: Continental, National and Institutional Realities. In Nwokeafor (Ed.,) Information Communication Technology (ICT) Integration to Educational Curricula: A New Direction for Africa, pp. 99-118.

Harrison. D. (2015). Educating tourism students in the South Pacific: changing cultures, changing economies. The Routledge Handbook of Tourism and Hospitality Education, Dredge, D. Airey, D., Gross M.J. (Eds.), pp. $225-$ 234.

Holden, H., \& Rada, R. (2011). Understanding the influence of perceived usability and technology self-efficacy on teachers' technology acceptance. Journal of Research on Technology in Education, 43(4), 343-367.

Hsu, H. C. C. (2015). Tourism and hospitality education in Asia. The Routledge Handbook of Tourism and Hospitality Education. Dredge, D. Airey, D., Gross M.J.(Eds.), pp. 197-209.

Joyce, M. (2013). Picking the best intercoder reliability statistic for your digital activism content analysis. Retrieved 16 November, 2015 from http://bit.ly/1mRgXoX

Klassen, R. M., Tze, V. M. C., Betts, S. M., \& Gordon, K. A. (2011). Teacher efficacy research 1998-2009: Signs of progress or unfulfilled promise? Educational Psychology Review, 23, 21-43.

Kuze, B. N. C. (2013). The implementation of tourism curriculum in secondary schools in Fort Beaufort Education District, Eastern Cape Province: implications for sustainable tourism. PhD thesis, University of Fort Hare.

Leso T., Peck K.L. (1992). Computer anxiety and different types of computer courses, Journal of Educational Computing Research, 8 (4) (1992), pp. 469-478.

Lewis, A. (2005). Rationalizing a tourism curriculum for sustainable tourism development in small island states: A stakeholder perspective. Journal of Hospitality, Leisure, Sport and Tourism Education, 4(2), 4-15.

Mayaka, M. A., Akama J. S. (2015). Challenges for tourism, hospitality and events higher education curricula in SubSaharan Africa: the case of Kenya. The Routledge Handbook of Tourism and Hospitality Education. Dredge, D. Airey, D., Gross M.J.(Eds.), pp. 235-262.

Muller, J., Sancho, J., Hernandez, F., Giro, X., \& Bosco, A. (2007). The socio-economic dimensions of ICT-driven educational change. Computers and Education, 494), 1175-1188.

Obijiofor, L. (2009). Mapping theoretical and practical issues in the relationship between ICT's Africa's socio-economic development. Telematics and Informatics, 17, 15-31.

Palak, D. \& Walls, R. (2009). Teachers' beliefs and technology practices: A mixed methods approach. Journal of Research on Technology in Education, 41(4), 417- 441.

Pawson P. (2002). A travel and tourism curriculum for the training of secondary school teachers. PhD thesis, University of South Africa.

Punt, L. F. (2010). Internal school moderation in the national curriculum statement: an application of grade 10 and 11 tourism in district North schools of the Western Cape education department. PhD thesis, Cape Peninsula University of Technology.

Schunk D., and Pajares F. (2009). Self-efficacy theory. K.R. Wentzel, A. Wigfield (Eds.), Handbook of motivation in school, Taylor Francis, New York (2009), pp. 35-54.

Shah, M. M., Hassan, R., \& Embi, R. (2012). Technology acceptance and computer anxiety. In 2012 international conference on innovation management and technology research (ICIMTR) (pp. 306-309).

Shalem, Y., \& Allais, S. (2014). Vocational subjects in the secondary curriculum -- what criteria count?. Paper presented at the European Conference on Educational Research, Porto, 2nd - 5th September 2014, Porto.

Sherry, M. (2008). Insider/Outsider Status. In Lisa M. Given (Ed.), The Sage Encyclopedia of Qualitative Research Methods. (pp. 433-434). Thousand Oaks, CA: SAGE Publications, Inc. doi: http://dx.doi.org/10.4135/9781412963909.n216

South African Tourism, (2014). International tourist arrivals to South Africa approach the 10-million mark. Retrieved 4 December 2015 from http://bit.ly/1N77nf6

Sumak, B., Hericko, M., \& Pusnik, M. (2011). A meta-analysis of e-learning technology acceptance: the role of user types and e learning technology types. Computers in Human Behavior, 27(6), 2067-2077.

Teo, T. (2011). Technology acceptance in education. Research and issues. Rotterdam: Sense Publishers

Umalusi (2014). Council for Quality Assurance in General and Further Education and Training. What's in the CAPS package? Tourism.

Van Niekerk, M. (2004). The development of a tourism curriculum evaluation model for secondary schools. PhD thesis, North West University.

Van Niekerk, M., \& Saayman, M. (2013). The influences of tourism awareness on the travel patterns and career choices of high school students in South Africa. Tourism Review, 68, 19-33.

Van Zyl, I.J. (2013). Technology encounters and the symbolic narrative. Localising the 'technology for development'experience in South African education settings. Unpublished PhD dissertation, Università della Svizzera italiana. 
Vandeyar, T. (2013). Practice as policy in ICT for education: Catalysing communities of practice in education in South Africa. Technology in Society, 35(4), 248-257.

Vandeyar, T. (2015). Policy intermediaries and the reform of e-Education in South Africa. British Journal of Educational Technology, 46(2), 344-359.

Weston M.E., Bain A. (2010). The end of techno-critique: the naked truth about 1:1 laptop initiatives and educational change, The Journal of Technology, Learning and Assessment, 9 (6).

WTTC (World Travel and Tourism Council), (2015). Travel \& Tourism, Economic Impact 2015 South Africa. Retrieved December 2015 from: http://bit.ly/1R4VWuj 
The Role of Digital Technology in Tourism Education: A Case Study of South African Secondary Schools

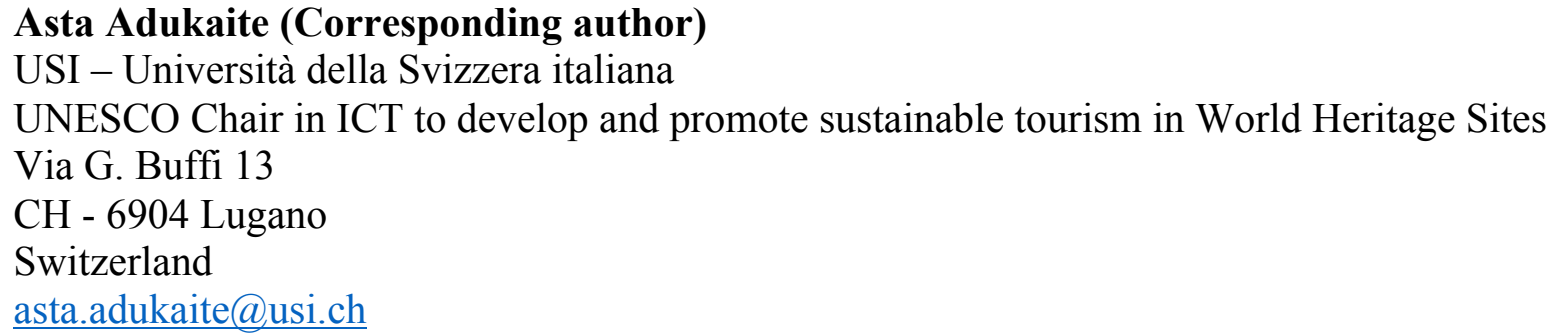

Lorenzo Cantoni

USI - Università della Svizzera italiana

UNESCO Chair in ICT to develop and promote sustainable tourism in World Heritage Sites, Via G. Buffi 13

$\mathrm{CH}$ - 6904 Lugano

lorenzo.cantoni@usi.ch 
Tourism Education and

Digital Technology in a

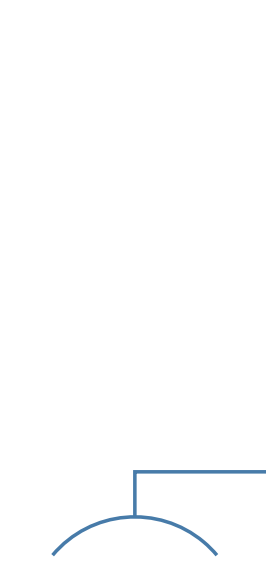

Suitable tech

infrastructure

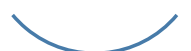

Developing and Emerging

Context

Potential: access, engagement and authentic learning

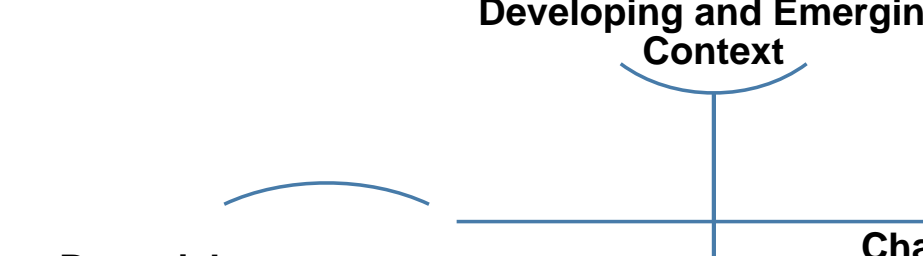

Challenges: tech anxiety,

insufficient self-efficacy, lack of

resources and skills

Symbolic, emotive and

cognitive potentials of

digital technology 